\title{
ナノカーボン材料とその応用
}

竹内 健司* - 藤重 雅嗣 - 野口 徹

\section{Nano Carbon Materials and Their Applications}

Kenji TAKEUCHI*, Masatsugu FUJISHIGE and Toru NOGUCHI(Institute of Carbon Science and Technology, Shinshu University, 4-17-1, Wakasato, Nagano 380-8553, Japan)*takeuchi@endomoribu.shinshu-u.ac.jp

Extraordinary chemical and physical properties of carbon nanotubes (CNTs) as well as the success of large-scale production by a catalytic chemical vapor deposition (CCVD) method, particularly with the use of a floating reactant technique, make them applicable in the fabrication of adsorbent, electrochemical electrode, and functional filler composite, etc at a possible low cost. Through judicious selection of transition metal, support materials and synthetic conditions (temperature, duration), it is possible to produce different types of CNTs such as multi-walled CNTs (MWCNTs), double-walled CNTs (DWCNTs)and single-walled CNTs (SWCNTs) selectively. In order to produce bulk quantities of CNT, a well-developed iron catalyst-based CCVD method so-called "Endo method" has been commonly used in the world. In this paper, we describe the synthetic techniques of various CNTs. The structural analysis will also be discussed in terms of nano-structure, and finally their practical applications of these CNTs will be described from the industrial point of view.

Key Words : Carbon Nanotubes, Chemical Vapor Deposition, Catalyst, Structure, Growth Control

\section{1. 緒言}

炭素はダイヤモンド, グラファイトからアモルファス炭 素, そしてカルビン, フラーレンと結合形態の異なる元素 中最多の同素体を有し，またそれらの結合が混在した状態 のカーボンナノチューブ（CNT）を含めて多様な物質群 を形成する. その機能も, 電気・電子, 機械, 熱, 化学, バイオ, 医療と多様かつ多彩である. 炭素原子の持つ $s p$, $s p^{2}, s p^{3}$ 結合の多様性が様々な炭素物質群を生み出し, 類 まれな “Carbon diversity (炭素種の多様性)”の根源と なっている，そこでの炭素は従来の延長線上ではない機能 に掠いて飛躍性を有したナノカーボンである.すなわちナ ノカーボンとは, 『ナノメータのレベルで精緻に微視的構 造や組織・形態が制御，設計され，それによって従来には ない高度な性能が付与され，あるいは革新的な機能を発現 する炭素体』と定義される(図1 ${ }^{1-5)}$. ナノカーボンの 科学と工学は, 炭素の $s p, s p^{2}, s p^{3}$ 結合を駆使して, ある いは炭素六員環構造をうまく縫合して目的にフィットさせ る, “Carbon tailor”を目指すものである。これによって 零次元, 一次元, 二次元のナノカーボンが得られる. 具体
的には“フラーレン”，“カーボンナノチューブ”，そして “グラフェン”がその代表である. 多様な炭素ファミリー の中でもナノテク・イノベーションの先導役ともいうべき CNTが, 広範な分野から注目され, ケイ素やゲルマニウ ムに代わって新たな世紀を拓く中心的な材料として期待さ

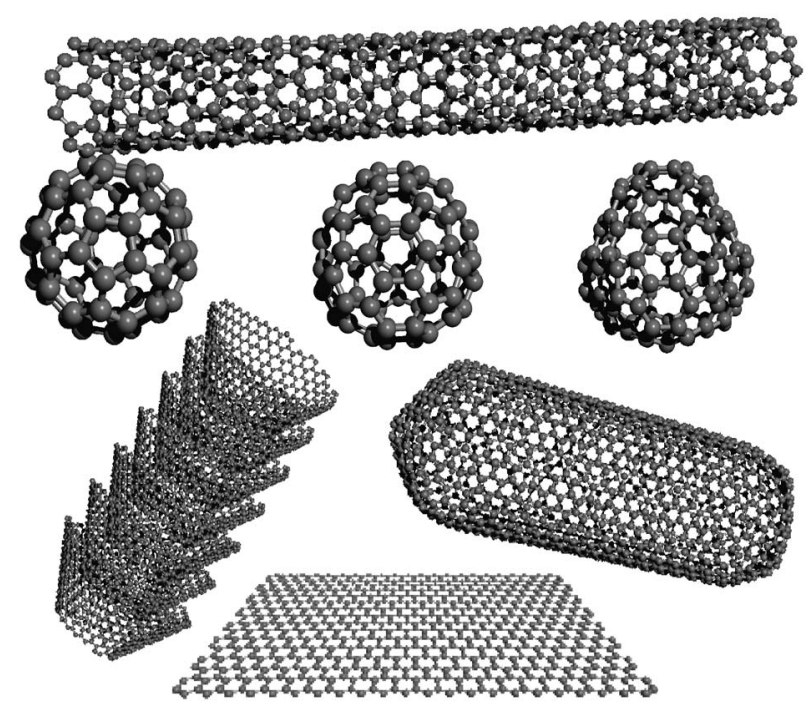

図 1 ナノカーボンの定義 
れている.

かかるCNTはナノテクを先導する材料として大きな期 待を集め，量産と応用開拓が進んでいる。現在，CNTの 生成法として触媒気相成長（CCVD）法が広く使われるよ うになり, 単層, 二層, 多層 $\mathrm{CNT}$ の基礎科学の確立, そ して産業化に加速度がついてきている。

本稿ではかかる CCVD法による各種 CNTについてその 構造制御や具体的応用例や展望について紹介したい。

\section{CNTの構造と生成法}

ナノカーボンの代表的な存在である CNTは，三次元ダ イヤモンド構造と二次元グラファイト構造がハイブリット された，両者の性質を合わせ持つ特異な構造体である（図 2).すなわちCNTは，『グラファイト六角網平面を筒状に 丸めた状態の構造をもつ欠陥の無い単層, あるいはそれら が入れ子状に積層した二層, 三層夕イプさらに多層のチュ ーブ状物質』と定義される. 直径は概ね数百ナノメートル (nm) 以下で，最小の直径である $0.43 \mathrm{~nm}$ のチューブも見 出されている ${ }^{6)}$. 特に単層や二層の CNTはその特異な構 造に起因する量子効果の発現により，チューブ径やグラフ アイト六角網平面のらせん角度の違いによって金属および 半導体的性質に変化することは良く知られている.

CNTの生成法には, (1)アーク放電 ${ }^{7)}$, (2)レーザ蒸発法 ${ }^{8)}$, (3) CCVD 法 ${ }^{9,10)}$ が知られている。アーク放電法とレーザ 蒸発法は, どちらも比較的高純度な CNTが容易に得られ るが，スケールアップに難があるのに対して，CCVD 法 は高純度量産性や構造制御性の観点から最も有効な生成法 である。CCVD法によるCNTの成長には，ナノサイズの 鉄粒子の触媒反応が不可欠であり，その機能によってチュ
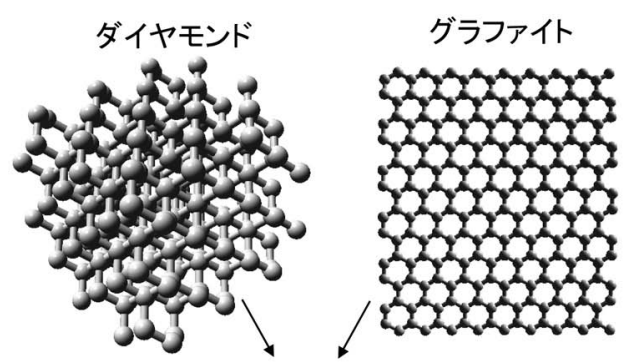

カ一ボンナノチューブ(CNT)
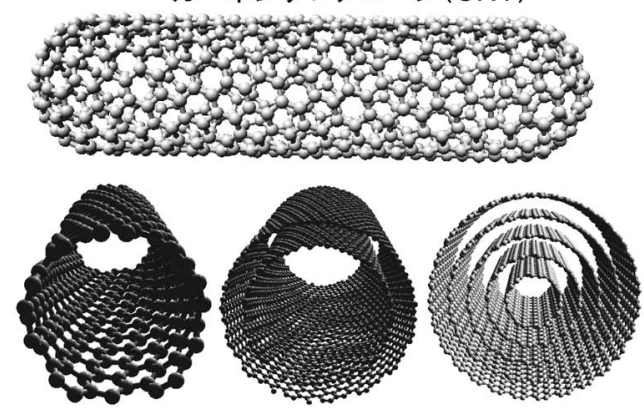

単層CNT

二層CNT

多層CNT

図2 カーボンの同素体とナノチューブの代表的な形態
ーブが形成される。多層CNT（MWCNT）が既に量産さ れ, そして最近では単層 CNT (SWCNT) や二層 CNT （DWCNT）の量産も実用化レベルに来ている。ことに単 層, 二層, 多層 CNTは選択的に成長制御が可能となり, 商業化も進められている。

元々 CCVD 法は古くから気相成長炭素繊維（VGCF）を 生成する手法として研究開発が進められていた手法である。 遠藤は1976年に自ら開発したCCVD法で調製したVGCFを 透過型電子顕微鏡 (TEM) で観察し, 単層や多層のCNT が混在していることを確認した、VGCFは触媒反応により 形成される極細中空チューブ（CNT）を基材としてその周 りに熱分解炭素層が沈積していくことで太く成長し，年輪 状の断面構造を構成している（図3） 11）。図3 はVGCFを液 体窒素中で破砕した断面写真であるが, 中心部のCNT と見 られる極細チューブは切れずに残っており, その周りの組 織とは明らかに構造が異なると考えられる ${ }^{12)}$. 特にCNT の優れた強度と構造に起因すると推定される機械的特性の 違いが興味深い.さらに不活性ガス中の高温熱処理後も極 細チューブが昇華せずVGCF の中心部に残留しており， CNTが熱的安定性に優れることを示唆している.

CNTの成長と直径制御に触媒金属が欠かせないことが 明らかにされている (図4) ${ }^{9)}$ 。この多層 CNTは, 直径数 $\mathrm{nm}$ 以下の鉄等の超微細な触媒粒子によって成長する ${ }^{9)}$.
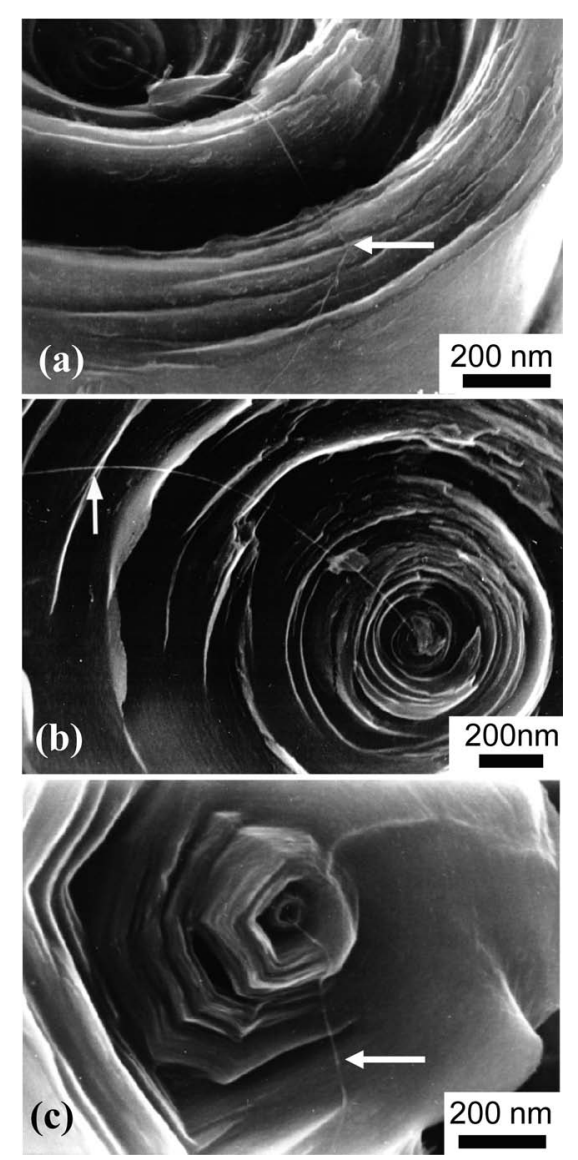

図3 気相成長炭素繊維（VGCF）の断面 SEM 写真（（a）（b） Asgrown, (c) $2800{ }^{\circ} \mathrm{C}$ 熱処理後) 
すなわち，CCVD 法 ${ }^{9,10,12,13)}$ は基本的には，ナノサイズの 鉄粒子を（I）基板上に分散したり（基板法） 9,10)，それ を（II）反応炉中で浮遊せしめ（浮遊法） ${ }^{13 ） ， あ る い は ~}$ （III）両者の中間法でシリカ等の微小粉体に鉄触媒を担持 して浮遊した状態で基材から成長させる方法が目的によっ て使い分けられている（図5）14,15)。（I）は構造や成長の 制御性に優れた生成法として電子デバイス形成法にも応用 されている，特に（II）は高純度のCNTを大量に生成す る上で効果的で, 単層, 二層 ${ }^{16)}$, 多層 $\mathrm{CNT}$ 生成に応用さ れ，10-20 nm 程度の細いMWCNT の低コスト生成法とし て（III）の方法も含めて世界各国で数社が総計約 $1,000 \mathrm{t} /$ 年規模で製造が展開されている.

最近の Nature 誌でも，MWCNT素材ベースで，2009年 で 100 億円，2015年で約 500 億円の市場規模と予測されて

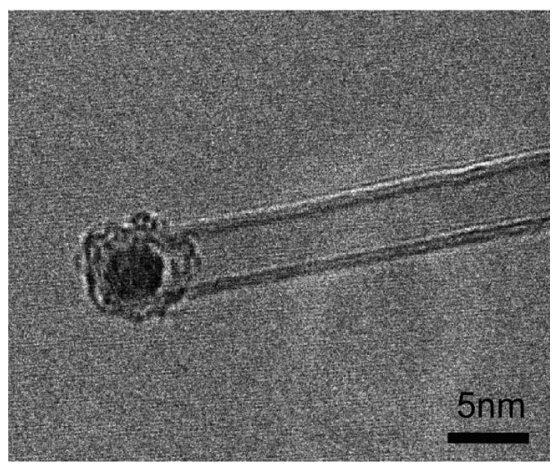

図4 先端に鉄触媒を持つCNT の TEM 写真
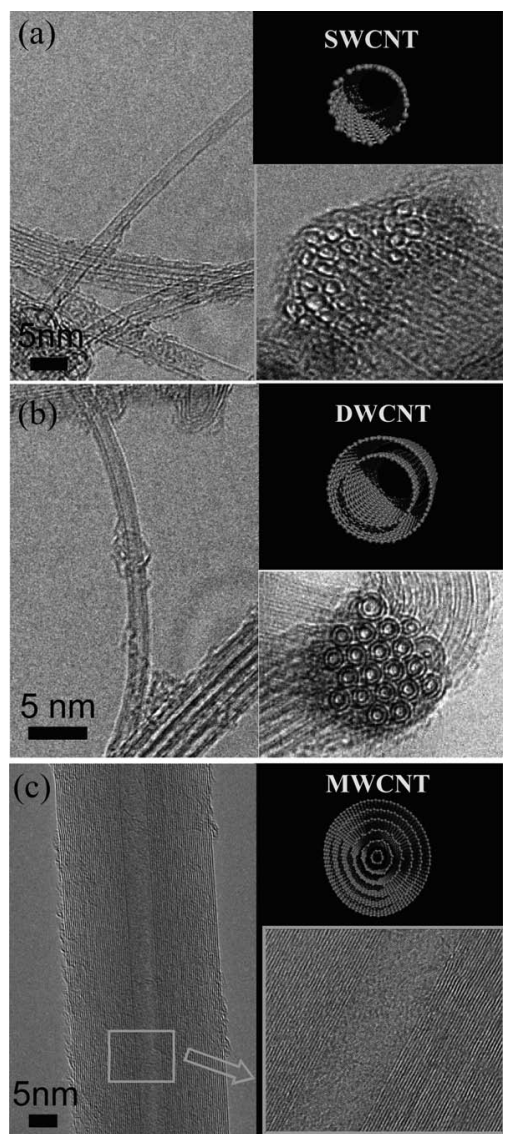

図 5 単層 $\mathrm{CNT}$ (a), 二層 $\mathrm{CNT}$ (b), 多層 $\mathrm{CNT}$ (c) の TEM写真
おり ${ }^{17)}$, 現在は世界市場での生産量も約 1,000 t/年を超え, いよいよCNTイノベーションが始まったと言えよう。 CCVD法により，触媒粒子を効果的に調製して単層，二 層，十数層の構造を制御したCNTも世界各国で量産化さ れつつあり, CCVD法の有効性と可能性が改めて評価さ れている。また構造の違いによって SWCNTの両端エッ ジ部位に異なった官能基が付与でき, 生成後の処理工程に よっても半導体，金属性 CNTの分離，精製法が開拓され つつある。これにより CNTの量子効果を用いた電子デバ イスやセンサへの応用の実現性がより高まっている.

\section{CNT の進展と応用}

CNTにおける構造の多様性はまさに“Carbon nanotubes diversity”を生み出し, 単層, 多層 CNTの物性に 加えより広い機能発現が可能となり, 特にCCVD法によ るCNTは広範な用途開拓に寄与するものとして期待され ている。CNTの生成研究は，1970年代から構造制御や大 量生成の容易な CCVD法を用いて精力的に行われてきて おり，かかるCCVD法によって現在は単層，二層から多 層までチューブ構造を任意に制御できるようになった。 CNTの特長を発揮した用途開拓はその機械的性能の反映 が最初であり，混練プロセスを経てもその形状が維持され ることは従来の炭素繊維には無い性質で各種複合材料に電 気，熱伝導性などの機能付与が可能となる.

かかる特長から実用的にはまず多層 CNTは携帯電子機 器等のリチウムイオン二次電池 (LIB) 用負極添加剤とし て市場実績を積んでいる ${ }^{18)}$ 。多層 CNTはLIBの高性能化 と安全性向上に大きく貢献し，待望のLIBを積んだプラグ インハイブリッド自動車には必須と目され，その重要度を 増している. LIB負極用黒鉛に添加されたCNTによって LIBのサイクル特性が大きく改善され, CNTが電極のグ ラファイト粒子を良好に連結する役割を果たす。CNTの 炭素ナノ構造に起因する材料中最高の復元性能 (resiliency）が，フレキシブルな導電性ネットワークを粒子間に 形成することに寄与している。多層 CNTはLIBの特長を 増強する不可欠の存在と認識され, 負極以外に正極の添加 剂としての期待も大きく19)，さらに広く実用が進むすう 勢にある.ナノサイズのチューブ状物質が惹起する特有の 物理, 化学的機能が, Liイオン電池の高性能化に寄与し ている.さらに各種二次電池, 一次電池, キャパシタへも 実用が拡大しようとしている。また最近は各種の先進複合 材としても市場に登場してきており，今後の発展が期待さ れている. 今後, CCVD法はCNTの直径, 積層数などを 正確に制御しつつ高純度大量合成技術を完成させ，触媒粒 子を設計してCNTのカイラルベクトルを精緻に調節でき る技術としてセンサ，半導体素子応用など単一チューブを 対象とした応用法へと発展しょう。 
複合材料はCNTの応用として最大の開発テーマであり, CNTの持つ優れた諸特性を生かした様々な複合材用のフ イラーとして活発に研究が展開されている. 現在, CNT をフィラーに用いた樹脂，金属，セラミックス等の革新的 な複合材料の開発が進められ，まず樹脂複合材料は半導体 製造用コンテナー，発電用風車などで地位が固まってきて いる．炭素繊維複合材料には無い機能発現で特長を出して おり, 今後, 自動車の車体や部品への展開も見えてきた.

航空機や自動車などの高速輸送インフラにおいて, 石油 ショック以降の燃料経費低減は依然大きな課題であり, 地 球環境への負荷低減の観点からも，軽量化が追求されてい る.このような状況を踏まえて様々なマトリクス樹脂やゴ ム，金属を対象とした多層 CNTをフィラーとした複合材 料についても応用研究が進んでおり，スポーツ用品等で一 部実用化が開始されている。目下のところ量的な制約から 複合構造や界面性能が中心的検討課題であるが，導電性， 加工性，熱伝導性等の機能付与が期待されている．炭素繊 維とは大きく異なる CNTの屈曲にも強い特異的な特性は, ポリカーボネート / CNT複合材料で自動車用として定着 しつつあり，車体の軽量化や塗装技術で貢献できよう。具 体的応用としては多層 CNTをベースとしたプラスチック 複合材が精密プラスチック用歯車として試作されており （図6）3,4,5,11)，また自動車用としても実用例がある。これ は成形性や形状安定性, 高い転写性能に優れるためで，機 械的機能の反映の他に，導電性，加工性，熱伝導性等の機 能付与等が期待されている. 特に直径 $3 \mathrm{~mm}$ 以下の精密歯 車はナノレベルで補強され，かつ摺動性に優れており，マ イクロマシニングそしてナノマシニング分野や $\mathrm{OA}$ 機器分 野での発展が期待できる.

通常の炭素繊維複合材料との併用でマトリクス樹脂に添加 することで三元系複合材料を構成し，さらに改善された機械 的性能が可能であり, 宇宙航空材料, 軽量自動車用部材とし て有望である。その他，アルミニウムやマグネシウム等の低 融点金属との複合材料も強度，熱伝導性等で特長が発揮され， チタン複合金属なども合わせて実用化が視野に入ってきた ${ }^{20)}$.

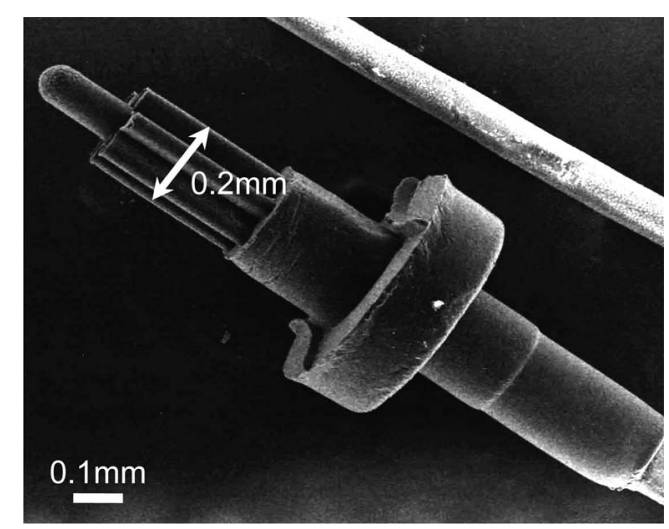

図6 多層 $\mathrm{CNT}$ ／樹脂複合材を用いた最小径の精密プラスチックギ アーと髪の毛のSEM写真
また二層CNTを用いた透明導電フィルム ${ }^{21)}$ の実用化は間近 い．遠藤らによって報告されている多層CNTに関する熱伝 導率の類推から，単層 $\mathrm{CNT}$ や多層 $\mathrm{CNT}$ では室温で 3,000〜 $6,000 \mathrm{~W} / \mathrm{mK}$ の高い熱伝導率が予測され，かかる複合材料に よって熱伝導機能で電子デバイスやレーザ素子冷却などの分 野で新規用途も開拓できよう。

現在，石油開発の技術は既に極めて過酷な環境の中にあ る。特殊な石油井を除けば，井中の環境は最高温度が 175 ${ }^{\circ} \mathrm{C}$, そして圧力が $140 \mathrm{MPa}$ に達する。この圧力は海底 $14,000 \mathrm{~m}$ の水圧に相当する環境である．石油探査におい ては探査装置の中にセンサ・計測器などが組み込まれてお り, 測定器はモジュール化され，ニーズに応じて組み立て られ，モジュール間の接合部にはゴムシール機構が不可欠 になる。そこで，表面改質を施した多層 CNTをフィラー に用いてCNT本来の物性に加えてフッ素ゴム（FKM）界 面相並びに立体構造の制御すなわち新開発のセルレーショ ン技術（CNTフィラーを細胞のセルのようにFKMマトリ ックスを包み込む構造で配置させる）によって，現行の $175{ }^{\circ} \mathrm{C}, 140 \mathrm{MPa}$ (標準仕様) のシール性能を, $260{ }^{\circ} \mathrm{C}$, $239 \mathrm{MPa}$ の革新的耐久性を有する超高性能ゴムシール材 に開発することに成功している（図7） ${ }^{22)}$ 。なお，極過酷

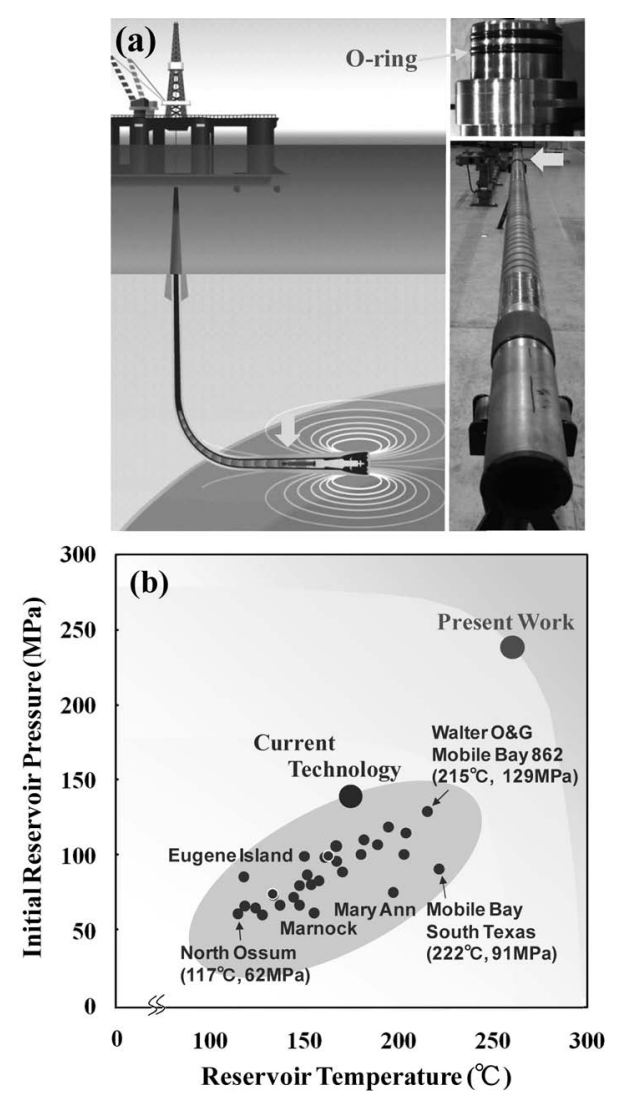

図7 現在の油田における温度と圧力の関係と CNT /ゴム複合材に よるシール材の達成值（260 $\left.{ }^{\circ} \mathrm{C} ， 239 \mathrm{MPa}\right)$ (M. Endo et al., Extreme-Performance Rubber Nanocomposites for Probing and Excavating Deep Oil Resources Using Multi-Walled Carbon Nanotubes, Advanced Functional Materials, 2008, 18, 3403-3409. Copyright Wiley-VCH Verlag GmbH \& Co. KGaA. Reproduced with permission.) 
環境下における実証実験に成功し，前人未踏の超高温・超 高圧油田に到達した。これらのゴム部品はすでに実用化の 段階に至っており，石油探査では全大陸で活用が始まって いる．本成果はこれまで生産が困難であった石油の探査， 採掘技術のイノベーションに貢献するものであり，石油資 源の供給能力の飛躍的向上をもたらし，エネルギー資源問 題の緩和に大きく寄与できるものと期待されている.

また，コネクタ等の接点材料に銀 $(\mathrm{Ag})$ 膜が多用され ているが，Agは大気中において容易に硫化されてしまい, 時にはショットキーコンタクトのような現象を起こしてし まう。この非オーミックなコンタクトは異常電気信号を引 き起こし，Agコンタクトにおいて長年の問題となってい る.そこで, $\mathrm{Ag} / \mathrm{CNT}$ 複合めっき膜が開発され, 硫化水 素ガスによる腐食試験を行うと，通常の $\mathrm{Ag}$ めっき膜では $0.2 \mathrm{~N}$ の低接触荷重の場合, 腐食後の $\mathrm{Ag}$ めっき膜の接触抵 抗は極性があり，高い抵抗值を示した。これに対して腐食 後の Ag-CNTめっき膜では腐食後でも接触抵抗に極性が なく，低抵抗であった ${ }^{23)}$. 今後，電気自動車が急速に普 及すると予測され，ガソリン車に比べ電気接点数が大幅に 増えると考えられ， $\mathrm{Ag} / \mathrm{CNT}$ 複合めっき膜のような耐腐 食性の高機能電気接点材料が期待されている.

ナノカーボンの機能と期待される応用を図 $8^{4,5,11,24)}$ に示 した。応用分野は，当面，IT，エネルギーや自動車産業 から進むと思われる。CNT応用の基礎科学が着実に構築 されており，電子源としてフラットパネルディスプレイや 蛍光灯に替わる光源，透明導電性 CNT 複合樹脂，医用複 合材料, ナノバイオ等の分野を初め, 燃料電池, 各種セン サ，トランジス夕，バリスティック導電材料など量子的機 能の応用など，今後，飛躍的な用途の拡大が期待できる.

炭素繊維の商業化は，釣り笔とゴルフクラブ向けに早い 段階で確立され，その後，産業分野の需要の増加に伴い航 空宇宙用途は約 10 年後に確立された。今後 CNT も炭素繊

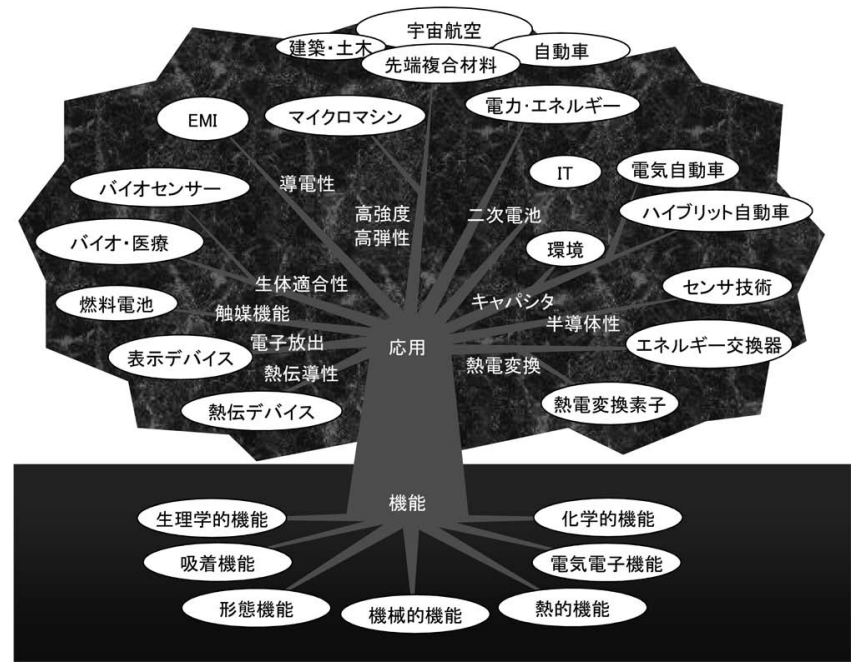

図8 CNTに関する新機能と応用の樹
維と同様な進歩の軌跡を辿ると期待される. 21 世紀のイ ノベーションを実現するナノテクを先導する材料として， 今後の科学と技術のバランス有る発展が一層重要となって きた。CNTは優れた諸特性により構造材用複合材料や新 電子素子応用など，広範な産業用途が期待できる。これら の特性を最大限に活用するためには高品質のチューブを再 現性良く安価に生成する手段の開発は極めて重要である.

\section{CCVD法による構造制御と新たな可能性}

各種 CNT の中で二層 CNT（DWCNT）は，量子効果の 発現, さらに優れた物理・化学および光学特性の観点から 期待されている。近年，通常の CCVD法をべースに特に 触媒を工夫することで，これまで困難であったチューブ径 を制御した高純度な DWCNTの製法を確立し（図 9） 16）, 量産に向けての可能性が開拓されている [4]。DWCNT の生成には，他にフラーレン $\left(\mathrm{C}_{60}\right)$ を単層 $\mathrm{CNT}$ に内包さ せたNano-Peapodを熱処理して $\mathrm{C}_{60}$ を融合させDWCNTへ 構造変化させる方法もあるが, CCVD法では効率よく高 純度で生成でき，かつ構造を制御するのに最適な方法で, これにより生成したDWCNT は高い構造完全性と熱安定 性を有している. 特にPeapod由来DWCNTは $2,200{ }^{\circ} \mathrm{C}$ 付 近の熱処理でチューブ構造が大きく変化するのに対して,

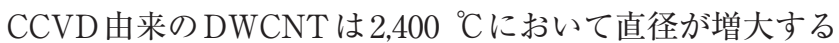
が構造は保たれており, 両者の熱安定性の差異は興味深い.

また，CCVD法により成長条件を制御して中空チュー ブ直径が $1 \mathrm{~nm}$ の極細二層構造を選択的に形成でき，この 構造特異性を利用してチューブ内にモリブデン原子を 1 次 元に並べた原子ワイヤーの形成に成功している（図 10） ${ }^{25)}$. 白金や金原子もチューブ内に 1 次元に整列させることが可 能でDWCNTで特異的に合成された。これまで単層 CNT や多層 CNTに鉄やニッケルなどの金属またはその酸化物

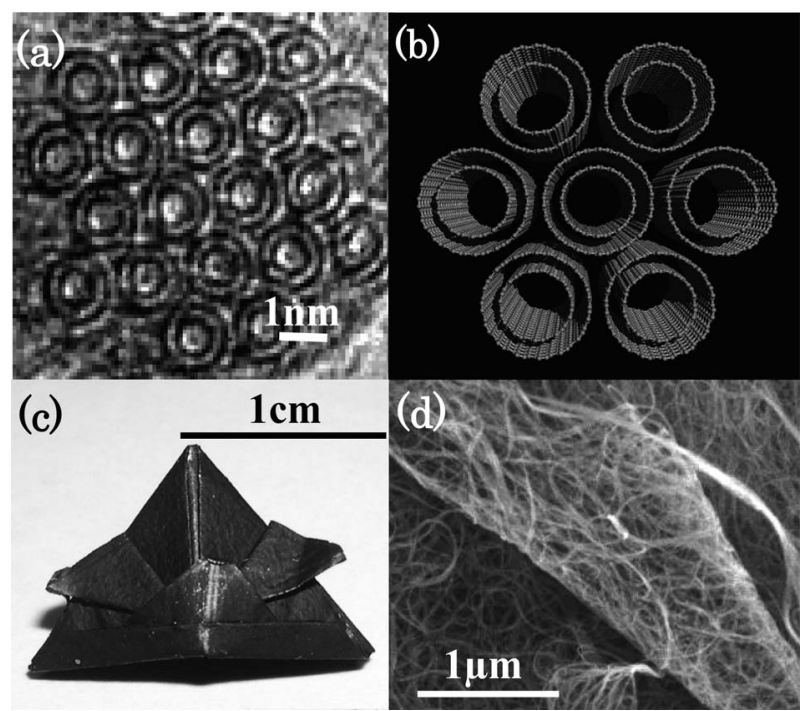

図 9 高純度二層 CNT の TEM 写真（a）と構造モデル（b)，二層 CNTペーパーによる折り紙 (c), 二層CNTのSEM写真 (d) 
等を直径数 $\mathrm{nm}$ のナノロッドとして内包させた報告はある が，金属原子をチューブ内に1次元に並べた点にブレーク スルーがあり，電子，触媒，磁性等の新機能性付与の観点 で期待が拡大している.

CNTは大量生成に有利な CCVD 法を用いて量産化が進 んでいるが，例えば金属や樹脂との複合材料向けのフィラ ーとして用いる場合，他のフィラーと比べて未だ高コスト である．複合材料用フィラーとしてのポテンシャルは非常 に高いので，今後製造コストが大きく下がれば多分野に亘 って需要が急激に増大すると推測される。そこで, 触媒と して鉄化合物を含む安価な天然鉱物であるガーネット粉末 (約 150 円 $/ \mathrm{Kg})$ に着目し，さらに炭素源に安価な都市ガ スをそれぞれ用いてCNTの生成が試みられている。その 結果，触媒にガーネット粉末を用いることで，これまでの 合成触媒と比べても極めて効率良く大量にかつ高品質の多 層 CNTの生成に成功している（図 11） ${ }^{26)}$ 。さらに，ガー ネットの表面に成長したCNTは，超音波処理により容易 に分離でき，実際にガーネットが触媒として繰り返し再利 用できることを確認した。CNTの低コスト生成法は非常 に重要であり，応用分野を広げるため本手法等をさらに発 展させて更なる低コスト化が必要である。また，かかる CCVD 法ではメタン原料と鉄触媒を反応せしめて製造す るのが一般的で，反応生成物はCNT，そして水素とメ夕 ンの混合ガスになる。これこそ新然料，ハイタン，であり， CNTとして炭素が固定された分は温暖化ガス低減に役立 つ、豊富なメタンから CNTが生産され，同時に環境にや さしい水素然料が製造できる。

各種 CNTの生成に関する研究が盛んに行われ，同領域 は従来に比べて進展している。しかしながら，CNTを今 後更に大きく発展させるためには，CNTの直径，積層数 などを制御し，高純度大量合成技術を確立させつつ，触媒 粒子を設計してCNTのカイラルベクトルを精緻に調節で きる技術の達成が不可欠である。そのためには生成機構の より詳細な解明と生成システムや触媒におけるブレークス ルーが必要である。また，CCVD法ではアーク放電法に 比べてより広範な直径のCNTが得られることが知られて いる.よって，カイラルベクトルの制御が可能になればそ

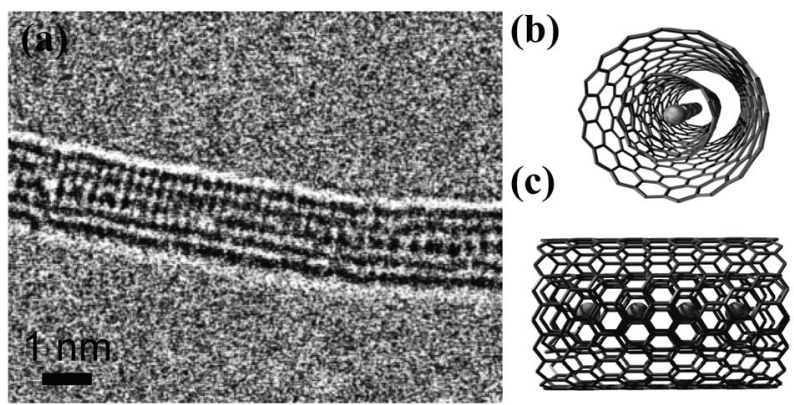

図 10 Mo 原子ワイヤーを内包した二層 CNT の TEM写真（a）およ びその構造モデル（b）（c）
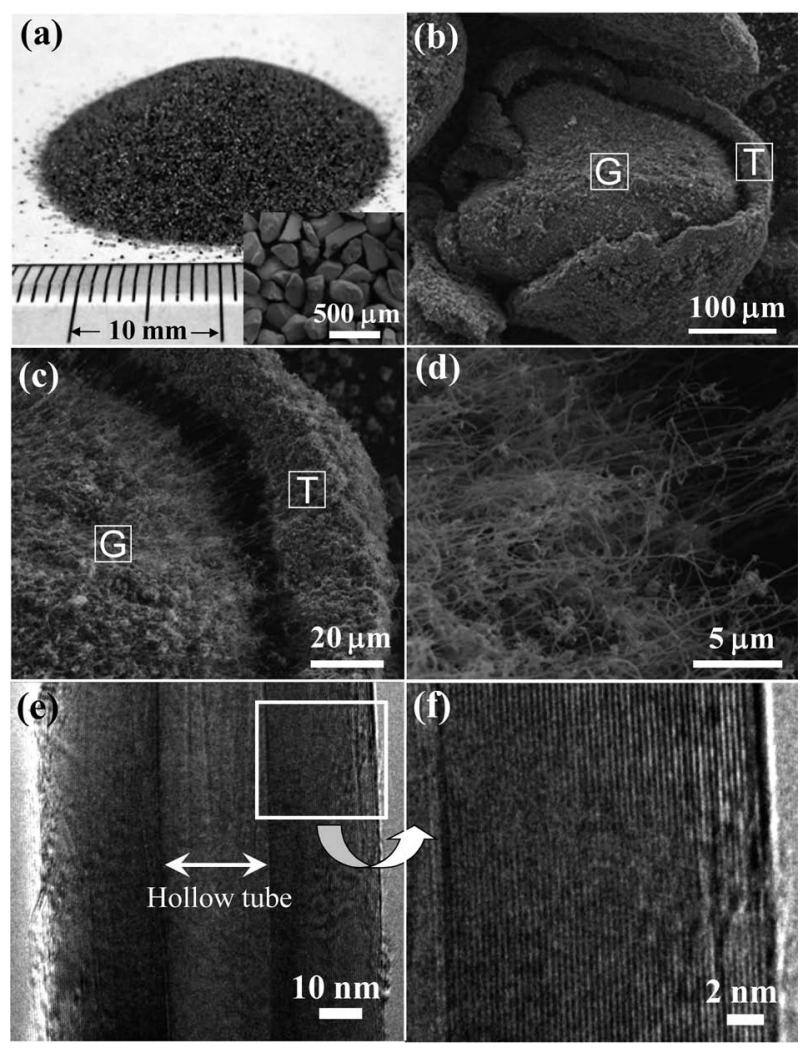

図11 ガーネットを用いた多層 CNT の顕微鏡写真（G; Garnet, T; Nanotube） ${ }^{20)}$. 用いたガーネット粉末（a），得られた多層 CNTのSEM 写真（b）（c）（d）およびTEM写真（e）（f） (M. Endo et al., Simple Synthesis of Multi-Walled Carbon Nanotubes from Natural Resources, ChemSusChem, 2008, 1, 820-822. Copyright Wiley-VCH Verlag GmbH \& Co. KGaA. Reproduced with permission.)

れによってトランジスタと導電回路形成や発光素子のよう な集積電子デバイスへの応用が期待できる.

前述したように現在のCNTの生成には構造制御や大量 生成の観点から CCVD法が主に用いられている。古くか ら開発された手法ではあるが，今後この方法をべースに 様々な検討がなされることで近い将来，上記のような課題 は解決できるものと考えられる。

\section{5. あ と が き}

従来の物質では達成できない卓越した，革新的機能を有 する“ナノカーボン”に代表される CNTは，ナノテクを 先導する材料として大きな期待を集めている. CNTは発 見から数十年が経過するが，今もなお CNTおよびその応

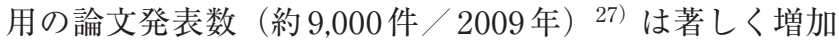
しており，この領域は最も活発な先端科学研究の一分野を 形成している，近年の傾向として産業応用関連の論文が増 加しており, 科学研究と産業化が並行して進められている ことの反映である.

CNTの生成法であるCCVD法は，低コスト，高純度で 量産可能であり，構造制御も容易であることから将来に亘 って大いに利用される手法である。今後，CNT生成技術 
が一層改善され，超長尺化および生成効率を 1,000 倍程度 高める必要がある.かつ純度や均質性が向上するに従って, 環境，資源，エネルギーさらにナノバイオ分野を中心に世 界規模での 21 世紀イノベーションに貢献するものと期待 される。『古くて，常に新しい素材，炭素』と言われるカ 一ボンは他に類を見ない特異なナノ構造や物性を有してお り，CNTに代表されるナノカーボンはその構造を巧みに 制御することが鍵となる。

CNTは様々な複合材料のフィラーとしてその特性向上に 寄与しているが，特に各種ゴムとの複合材料は熱特性や機 械特性の向上など革新的な技術となり得る大きな可能性を 秘めており，今後の更なる進展に期待したい. 当面 CNTは, その他複合材料を中心に応用が大きく展開されると考えら れる。多層 CNTの安全性も視野に入れて予防的アプローチ を遵守し，責任ある製造と応用を前提とし，CNTグリー ン・イノベーションに広く貢献を果たすことを期待したい。

\section{References}

1 ) Endo, M.: Mol. Crys. Liq. Cryst., 386, 159 (2002)

2 ) Inagaki, M.; Radovic, L. R.: Carbon, 40, 2279 (2002)

3 ) Iyoda, M.; Enoki, T.; Tamaura, Y. (Eds.) : Tanso No Jiten, Asakura Shoten, 5-2 (Endo, M.) (2007)

4 ) Endo, M.; Iijima, S. (Eds.) :Nano Carbon Hand book, NTS, 1-11, 1-2-1 (2007)

5 ) Takeuchi, K.; Park, K. C.; Hayashi, T.; Muramatsu, H.; Iinou, S.; Endo, M.: Plastics Age, III-2., p.81 (2009)

6 ) Hayashi, T.; Kim, Y. A.; Matoba, T.; Esaka, M.; Nishimura, K.; Tsukada, T.; Endo, M.: Nano Letters, 3, 887 (2003)

7 ) Iijima, S.: Nature, 354, 56 (1991)

8 ) Thess, A.; et al.: Science, 273, 483 (1996)

9 ) Oberlin, A.; Endo M.; Koyama, T.: J. Cryst. Growth, 32, 335 (1976)

10) Endo, M.; Takeuchi, K.; Igarashi, S.; Kobori, K.; Shiraishi, M.; Kroto, H. W.: J. Phys. Chem. Solids, 54, 1841 (1993)

11) Saito, R.; Shinohara, H. (Eds.) : "Carbon Nanotubes No Kiso To Ouyo” , 22 (Endo, M.), Baifukan (2004)

12) Endo, M.; Takeuchi, K.; Hiraoka, T.; Furuta, T.; Kasai, T.; Sun, X.; Kiang C.-H.; Dresselhaus, M. S.: J. Phys. Chem. Solids, 58, 1702 (1997)

13) Endo, M.: Chem. Tech., 18, 568 (1988)

14) Endo, M.: Jpn. Tokkyo Koho1244607 (1984)

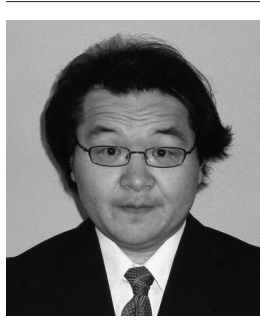

竹内 健司 ; 信州大学（广380-8553 長野市若 里 4-17-1） カーボン科学研究所准教授. 平成 8 年信州大学大学院博士課程修了. 専門は, カ ーボンナノチューブの生成と構造解析および 応用に関する研究
15) Endo, M.: Jpn. Tokkyo Koho1400271 (1987)

16) Endo, M.; Muramatsu, H.; Hayashi, T.; Kim, Y. A.; Terrones, M.; Dresselhaus M. S.: Nature, 433, 476 (2005)

17) BUSINESS WATCH (NEWS BRIEFING) : Nature, 461, 703 (2009)

18) Endo, M.; Kim, Y. A.; Hayashi, T.; Nishimura, K.; Matushita, T.; Miyashita, K.; Dresselhaus, M. S.: Carbon, 39, 1287 (2001)

19) Sotowa, C.; Origi, G.; Takeuchi, M.; Nishimura, Y.; Takeuchi, K.; Kim, Y. J.; Hayashi, T.; Kim, Y. A. ; Endo, M.; Dresselhaus, M. S.: ChemSusChem, 1, 911 (2008)

20) Shimizu, Y.; Miki, S.; Soga, T.; Itoh, I.; Todoroki, H.; Hosono, T.; Sakaki, K.; Hayashi, T.; Kim, Y. A.; Endo, M.; Morimoto, S.; Koide, A.: Scripta Materialia, 58, 267 (2008)

21) Jung, Y. C.; Shimamoto, D.; Muramatsu, H.; Kim, Y.A.; Hayashi, T.; Terrones, M.; Endo, M.: Adv. Mater., 20, 4509 (2008)

22) Endo, M.; Noguchi, T.; Ito, M.; Takeuchi, K.; Hayashi, T.; Kim, Y. A.; Wanibuchi, T.; Jinnai, H.; Terrones, M.; Dresselhaus, M. S. : Adv. Funct. Mater., 18, 3403 (2008)

23) Fujishige, M.; Sekino, M.; Fujisawa, K.; Morimoto, S.; Takeuchi, K.; Arai, S.; Kawai, A.: Appl. Phys. Express, 3, 065801 (2010)

24) Endo, M.; Kim, Y. A.; Hayashi, T.; Terrones M.; Dresselhaus, M. S.: "Carbon Nanotubes and Other Carbon Materials" , in Encyclopedia of Nanoscience and Nanotechnology, Marcel Dekker (2004)

25) Muramatsu, H.; Hayashi, T.; Kim, Y. A.; Shimamoto, D.; Endo, M.; Terrones, M.; Dresselhaus, M. S.: Nano Letters, 8, 237 (2008)

26) Endo, M.; Takeuchi, K.; Ichiki, T.; Kim, Y. A.; Park, K. C.; Hayashi, T.; Fukuyo, T.; Iinou, S.; Su, D. S.; Terrones, M.; Dresselhaus, M. S.: ChemSusChem, 1, 820 (2008)

27) Tao, Y; Endo, M.; Kaneko K.: "Recent Progress on Synthesis and Applications of Carbon Nanotubes" , in Handbook of Innovative Nanomaterials: From Synthesis and Applications (Edited by X. Fang and L. Wu), Pan Stanford Publishing, 2010 (in press)

\section{日本語表記参考文献}

3 ) 伊予田正彦, 榎敏明, 玉浦裕 編：炭素の事典, 5-2（遠藤守信）, 朝倉書店 (2007)

4 ）遠藤守信，飯島澄男 監修：ナノカーボンハンドブック，1-1-1, 12-1，エヌ・ティー・エス (2007)

5 ) 竹内健司, 朴基哲, 林卓哉, 村松寛之, 飯生悟史, 遠藤守信 : プラスチックエージ， III-2., p.81 (2009)

11）斎藤理一郎, 篠原久典 編：カーボンナノチューブの基礎と応用, 22 章 (遠藤守信)，培風館（2004）

14）遠藤守信他：特許番号第 1244607 号 1984 年

15）遠藤守信他：特許番号第 1400271 号 1987 年

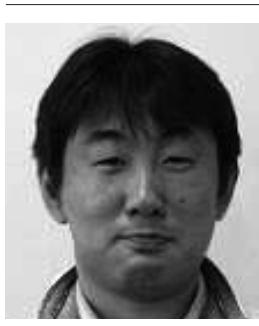

藤重 雅嗣; 信州大学カーボン科学研究所 : 研究員 ( 380-8553 長野市若里 4-17-1 総合研究棟8F コアラボ)。平 成 12 年広島大学大学院工学系研究課修士修了, 平成 21 年 信州大学総合工学系研究科博士課程後期修了. 平成 12 年 ～平成 15 年：侏从くに工業，平成 15 年〜平成 21 年：信 州大学工学部プロジェクト企業派遣研究員, 平成 21 年 現在：信州大学カーボン科学研究所研究員．専門は，電 気接点, 金属・ナノカーボン複合材料，めっきに関する 研究開発や環境問題に従事

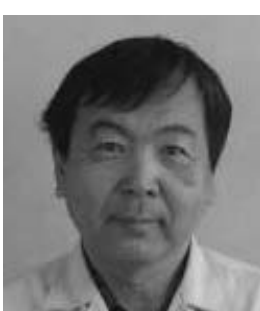

野口徽；日信工業(侏)，信州大学兼務：日信工業(秼)開 発本部・上席主幹（３３86-8567 上田市常田3-15-1＼cjkstart信州 大学繊維学部内 AREC15研究室), 信州大学エキゾチッ ク・ナノカーボンの創成と応用プロジェクト拠点・地域卓 越特任教授（干 380-8553 長野市若里 4-17-1 信州大学工 学部内SASTec $2 \mathrm{~F}$ ラボ 6 ). 昭和 52 年東北大学工学部卒 業, 昭和 61 年神戸大学大学院修了. 昭和 61 年 平成 13 年:三ツ星ベルト(株)，平成 14 年〜現在:日信工業(制，平成 22 年 信州大学特任教授兼務。専門は高分子，複合材料 の構造と物性 